\title{
Nonviral Approaches for Neuronal Delivery of Nucleic Acids
}

\author{
Jamie M. Bergen, ${ }^{1}$ In-Kyu Park, ${ }^{1}$ Philip J. Horner, ${ }^{1,2}$ and Suzie H. Pun ${ }^{1,3}$
}

Received June 12, 2007; accepted August 20, 2007; published online October 12, 2007

\begin{abstract}
The delivery of therapeutic nucleic acids to neurons has the potential to treat neurological disease and spinal cord injury. While select viral vectors have shown promise as gene carriers to neurons, their potential as therapeutic agents is limited by their toxicity and immunogenicity, their broad tropism, and the cost of large-scale formulation. Nonviral vectors are an attractive alternative in that they offer improved safety profiles compared to viruses, are less expensive to produce, and can be targeted to specific neuronal subpopulations. However, most nonviral vectors suffer from significantly lower transfection efficiencies than neurotropic viruses, severely limiting their utility in neuron-targeted delivery applications. To realize the potential of nonviral delivery technology in neurons, vectors must be designed to overcome a series of extra- and intracellular barriers. In this article, we describe the challenges preventing successful nonviral delivery of nucleic acids to neurons and review strategies aimed at overcoming these challenges.
\end{abstract}

KEY WORDS: CNS; neuron targeting; nonviral gene delivery; nucleic acid delivery.

\section{INTRODUCTION}

Inflictions of the central nervous system, including spinal cord injury and neurodegenerative diseases, are devastating disorders for which there are currently few treatment options. Continuing elucidation of the molecular mechanisms underlying the pathology associated with these disorders will enable the development of treatment strategies that reverse neuropathology at the molecular level. Nucleic acid-based therapy has the potential to address the molecular cause of neurological disease by manipulating gene expression profiles in targeted cells in the central nervous system (CNS). Although the role of various cell types in CNS disorders is still being elucidated, this review focuses on neuronal therapies. Two approaches for nucleic acid-based therapy which have been studied for the treatment of neurological disease include gene therapy and gene silencing. CNStargeted gene therapy can be accomplished by introducing genes encoding neurotrophic growth factors or corrective enzymes to injured or diseased neurons (1-5). In several animal models of neurodegenerative disease, gene therapy has achieved dramatic pathologic and functional improvements (6-13). Additionally, gene silencing strategies such as RNA interference (RNAi) can be implemented to reduce the expression levels of toxic proteins associated with neurological disease, and to minimize growth inhibitory signals

\footnotetext{
${ }^{1}$ Bioengineering, University of Washington, Box 355061, $1705 \mathrm{NE}$ Pacific St, Seattle, Washington 98195, USA.

${ }^{2}$ Neurological Surgery, University of Washington, Box 359655, Seattle, Washington 98195, USA.

${ }^{3}$ To whom correspondence should be addressed. (e-mail: spun@ u.washington.edu)
}

associated with spinal cord injury (14-16). The potential of RNAi-based therapies for the treatment of neurological disease has recently been demonstrated in animal models of spinocerebellar ataxia, Huntington's disease, amyotrophic lateral sclerosis, and Alzheimer's disease (17-20). Examples of disease-specific nucleic acid therapy approaches are summarized in Table 1.

Genes packaged in viral vectors, such as adeno-associated virus (AAV) or herpes simplex virus (HSV), remain the leading therapeutic candidates for neuron-targeted nucleic acid therapy, as they have produced functional improvement in several animal models of neurodegenerative disease. The few clinical trials that have been undertaken to treat neurodegenerative disease have employed viral vectors almost exclusively. However, significant complications associated with viral delivery limit its widespread clinical use. For example, the injection of HSV into mammalian tissue elicits a local immune response (21). Also, neutralizing antibodies against AAV in humans may be produced due to previous exposure (22); this complication has delayed clinical trials using AAV. Although viral vectors can be genetically modified to remove viral components that trigger an immune response, these modified viruses are often difficult to produce in high titer. Given the shortcomings associated with the clinical use of viral vectors, a critical need remains for vectors that deliver therapeutic nucleic acid cargo as efficiently as viruses, but which are safer to administer in vivo. Nonviral vectors, which offer improved safety profiles compared to viruses, represent a promising alternative to viruses for gene therapy applications. However, to realize the potential of nonviral gene delivery technology for CNS delivery applications, the limited transfection efficiencies of nonviral vectors must be addressed. 
Table 1. Examples of Nucleic Acid Delivery Resulting in Pathologic and/or Behavioral Improvements in Animal Models of Neurodegenerative Disease

\begin{tabular}{|c|c|c|c|c|}
\hline Disease/Model & Therapeutic Nucleic Acid & Vector/Delivery Location & Therapeutic Endpoints & Reference \\
\hline \multirow[t]{2}{*}{$\begin{array}{l}\text { Alzheimer's } \\
\text { Disease/APP } \\
\text { mouse model }\end{array}$} & DNA encoding neprilysin & $\begin{array}{l}\text { Herpes simplex virus/ } \\
\text { Hippocampal injection }\end{array}$ & $\begin{array}{l}\text { Pathologic: Reduced } \\
\text { amyloid production } \\
\text { and accumulation }\end{array}$ & (13) \\
\hline & $\begin{array}{l}\text { DNA encoding shRNA } \\
\text { against beta-secretase }\end{array}$ & $\begin{array}{l}\text { Lentivirus/Hippocampal } \\
\text { injection }\end{array}$ & $\begin{array}{l}\text { Pathologic: Reduced } \\
\text { amyloid production and } \\
\text { neuropathology } \\
\text { Behavioral: Ameliorated } \\
\text { behavioral deficits }\end{array}$ & (20) \\
\hline \multirow{5}{*}{$\begin{array}{l}\text { Parkinson's } \\
\text { Disease/6-OHDA } \\
\text { induced rat model } \\
\text { of Parkinson's }\end{array}$} & DNA encoding GDNF & $\begin{array}{l}\text { Adeno-associated virus/ } \\
\text { Intranigral injection }\end{array}$ & $\begin{array}{l}\text { Pathologic: Protected } \\
\text { nigral neurons }\end{array}$ & (8) \\
\hline & & $\begin{array}{l}\text { Adenovirus/Intrastriatal } \\
\text { injection }\end{array}$ & $\begin{array}{l}\text { Pathologic: Protected } \\
\text { nigral neurons } \\
\text { Behavioral: Prevented } \\
\text { motor impairment }\end{array}$ & (9) \\
\hline & & $\begin{array}{l}\text { Neurotensin-polyplex/ } \\
\text { Intranigral injection }\end{array}$ & $\begin{array}{l}\text { Pathologic: Protected } \\
\text { nigral neurons } \\
\text { Behavioral: Prevented } \\
\text { motor impairment }\end{array}$ & (10) \\
\hline & $\begin{array}{l}\text { DNA encoding tyrosine } \\
\text { hydroxylase }\end{array}$ & $\begin{array}{l}\text { Herpes simplex virus/ } \\
\text { Intrastiatal injection }\end{array}$ & $\begin{array}{l}\text { Pathologic: Increased striatal } \\
\text { tyrosine hydroxylase activity } \\
\text { Behavioral: Reversal of } \\
\text { motor impairment }\end{array}$ & (12) \\
\hline & & $\begin{array}{l}\text { PEGylated immunoliposomes/ } \\
\text { Intravenous administration }\end{array}$ & $\begin{array}{l}\text { Behavioral: Reversal of } \\
\text { motor impairment }\end{array}$ & (11) \\
\hline \multirow[t]{2}{*}{$\begin{array}{l}\text { Amyotrophic Lateral } \\
\text { Sclerosis (ALS)/ } \\
\text { SOD1 mouse model }\end{array}$} & $\begin{array}{l}\text { DNA encoding insulin } \\
\text { growth factor } 1\end{array}$ & $\begin{array}{l}\text { Adeno-associated virus/ } \\
\text { Intramuscular injection }\end{array}$ & $\begin{array}{l}\text { Pathologic: Delayed } \\
\text { astroglial response } \\
\text { Behavioral: Improved } \\
\text { motor performance and } \\
\text { prolonged survival }\end{array}$ & (6) \\
\hline & $\begin{array}{l}\text { DNA encoding shRNA } \\
\text { against mutant SOD1 }\end{array}$ & $\begin{array}{l}\text { Lentivirus/Intramuscular } \\
\text { injection }\end{array}$ & $\begin{array}{l}\text { Pathologic: Improved motor } \\
\text { neuron survival } \\
\text { Behavioral: Improved } \\
\text { motor performance } \\
\text { and prolonged survival }\end{array}$ & (19) \\
\hline \multirow{2}{*}{$\begin{array}{l}\text { Huntington's Disease/ } \\
{ }^{a} \text { Rats with striatal } \\
\text { lesions; }{ }^{b} \mathrm{HD} \text { mouse } \\
\text { model (expresses } \\
\text { mutant huntingtin) }\end{array}$} & $\begin{array}{l}{ }^{a} \text { DNA encoding GDNF or } \\
\text { BDNF }\end{array}$ & $\begin{array}{l}\text { Adeno-associated virus/ } \\
\text { Intrastriatal injection }\end{array}$ & $\begin{array}{l}\text { Pathologic: Reduced loss of } \\
\text { striatal neurons }\end{array}$ & (7) \\
\hline & $\begin{array}{l}{ }^{b} \text { DNA encoding shRNA } \\
\text { against mutant huntingtin }\end{array}$ & $\begin{array}{l}\text { Adeno-associated virus/ } \\
\text { Intrastriatal injection }\end{array}$ & $\begin{array}{l}\text { Pathologic: Reduced mutant } \\
\text { huntingtin inclusions } \\
\text { Behavioral: Improved gait } \\
\text { and motor coordination }\end{array}$ & (18) \\
\hline $\begin{array}{l}\text { Spinocerebellar ataxia } \\
\text { (SCA)/SCA1 } \\
\text { mouse model }\end{array}$ & $\begin{array}{l}\text { DNA encoding shRNA } \\
\text { against mutant ataxin-1 }\end{array}$ & $\begin{array}{l}\text { Adeno-associated virus/ } \\
\text { Intracerebellar injection }\end{array}$ & $\begin{array}{l}\text { Pathologic: Reduced ataxin-1 } \\
\text { inclusions } \\
\text { Behavioral: Improved } \\
\text { motor coordination }\end{array}$ & (17) \\
\hline
\end{tabular}

Examples included in the table are limited to treatment approaches involving in vivo administration of gene vectors, although ex vivo gene therapy approaches offer promising treatment options for neurological disorders as well.

\section{NONVIRAL VEHICLES FOR NEURONAL NUCLEIC ACID DELIVERY}

Realizing the potential of nonviral gene therapy to neurons will require the development of synthetic vectors that are capable of mediating efficient delivery of therapeutic nucleic acids into the targeted cells. The ideal vector will efficiently condense and protect nucleic acid cargo, target specific neuronal subpopulations in the body, and mediate appropriate intracellular delivery of the therapeutics. Toward this goal, research efforts have focused on evaluating existing vectors and developing new vectors for efficient neuronal transfection. The various classes of nonviral carriers that have been evaluated for neuronal gene delivery are described in the following sections. 


\section{Nonviral Carriers for Neuronal Transfection}

Polymers

Cationic polymers efficiently condense nucleic acids into nanoparticles, termed "polyplexes," by self-assembly via electrostatic interactions. An attractive feature of many polymeric vectors is that they contain functional groups that can be modified with ligands such as cell-targeting molecules (23). A number of cationic polymers have been studied for their ability to mediate nucleic acid delivery into neurons, although poly-L-lysine (PLL) and poly(ethylenimine) (PEI) are most widely represented in the literature (see Fig. 1 for polymer structures). PEI was introduced as a versatile nonviral gene carrier over a decade ago by Boussif et al. (24). Whereas previously studied polymer-based gene vectors, such as PLL, showed minimal neuronal transfection, optimized formulations of PEI showed significant reporter gene expression in cultured chick embryonic neurons and in newborn mouse brains. The higher gene delivery efficiency of PEI compared to PLL is attributed to its enhanced endosomal release capability $(24,25)$. Abdallah et al. (26) further demonstrated that, following direct brain injection in mature mice, the gene transfer capabilities of PEI-based polyplexes surpassed those of HIV-derived vectors and were comparable to those of adenoviral vectors. Still, polyplexes and other nonviral agents are typically less efficient than neurotropic viruses such as HSV for gene delivery to neurons (27). Additionally, the tendency of PEI/DNA polyplexes to aggregate in biological fluids and the cellular toxicity of PEI limit their potential application toward nucleic acid therapy. Grafting the hydrophilic polymer poly(ethylene glycol) (PEG) onto PEI-based polyplexes has been shown to prevent particle aggregation and reduce cellular toxicity following administration to the CNS $(28,29)$. To target polyplexes to specific neuronal subpopulations, polymers have been modified with cell-targeting ligands, which will be discussed in more detail later in this article.

Lipids

Cationic lipids are among the most efficient nonviral vectors, and have been used extensively to transfect cultured neurons for studies in basic neuroscience. While their transfection efficiency is typically surpassed by viral vectors, their utility derives from their ease of use and their large nucleic acid capacity. The various commercially-available cationic lipid formulations are typically composed of some combination of a cationic lipid such as 1,2-dioleoyl-3-trimethylammonium propane (DOTAP), $N$-methyl-4-(dioleyl)methylpyridinium

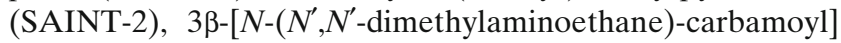
cholesterol (DC-Chol), or GS1, as well as the neutral lipid dioleoylphosphatidylethanolamine (DOPE) and cholesterol (see (30) for a recent review describing cationic lipids and lipoplexes for gene delivery). The simple addition of polyanionic nucleic acids to mixtures of cationic lipids or liposomes results in their self-assembly into particles termed "lipoplexes." While early cationic lipid formulations yielded approximately $1-3 \%$ transfected cells in primary neuronal cultures (31-33), newer formulations such as LIPOFECTAMINE ${ }^{\mathrm{TM}}$ 2000 (L2K) afford $\sim 20-25 \%$ transfected primary neurons (34).
Despite their relatively efficient transfection of cultured neurons, the in vivo delivery of cationic lipid-based carriers has been challenged by their tendency to aggregate in biological fluids (35). As an alternative, Pardridge (36) introduced PEGylated immunoliposomes (PILs), which consist of plasmid DNA encapsulated by PEG-modified neutral lipids. Unlike cationic liposomes, PILs retain colloidal stability in the blood following intravenous administration. By tethering targeting ligands such as transferrin or antibodies to the ends of the PEG strands, PILs have been shown to mediate efficient nucleic acid delivery to neurons in the CNS following systemic administration (37-39).

\section{Polypeptides/Proteins}

Engineered polypeptides are an appealing delivery platform because they can be designed modularly, incorporating functionalities for nucleic acid condensation, neuronal targeting, endosomal escape, and nuclear entry into a single recombinant protein. Efforts in this area have focused on the design of recombinant fusion proteins based on the tetanus toxin fragment $\mathrm{C}$ for neuronal targeting with additional domains for endosomal escape and DNA condensation mediated by the translocation domain of diphtheria toxin and the GAL4 transcription factor DNA-binding domain, respectively (40). Chimeric proteins were more efficient for transfection of cultured, neuron-like cells than mutants lacking one or more of the functionalities. Similar strategies employing nerve growth factor (NGF)-derived targeting peptides have also been described (41-43). In these studies, neuron-specific transfection was achieved using chimeric complexes consisting of either loop 4 of NGF or an NGF hairpin motif containing loops 1 and 2 fused to a DNAbinding domain.

\section{Nanoparticles}

Recent advances in nanotechnology have inspired the development of nonviral gene carriers based on synthetic nanoparticles. As an early example, it was demonstrated that gold nanoparticles coated with plasmid DNA could be delivered into cultured neurons through biolistic particle bombardment (44). However, fewer than $10 \%$ of neurons in primary culture were transfected by this method, and biolistic particle bombardment is not practical for therapeutic applications requiring in vivo delivery. Iron oxide nanoparticles coated with PLL demonstrated better in vivo success, as they bound DNA and mediated reporter gene expression in neurons and glia of the brain following intravenous injection (45). Also, it was recently demonstrated that amino-terminated organically modified silica (ORMOSIL) nanoparticles complexed with plasmid DNA were capable of transfecting neuronal cells following intraventricular injection at levels similar to HSV with fewer toxic or immunological side effects (46).

\section{Naked DNA}

In addition to the nonviral carriers for neuronal transfection described in the previous sections, physical methods have also been employed to efficiently deliver nucleic acids to cultured neurons. The electroporation-based technique 


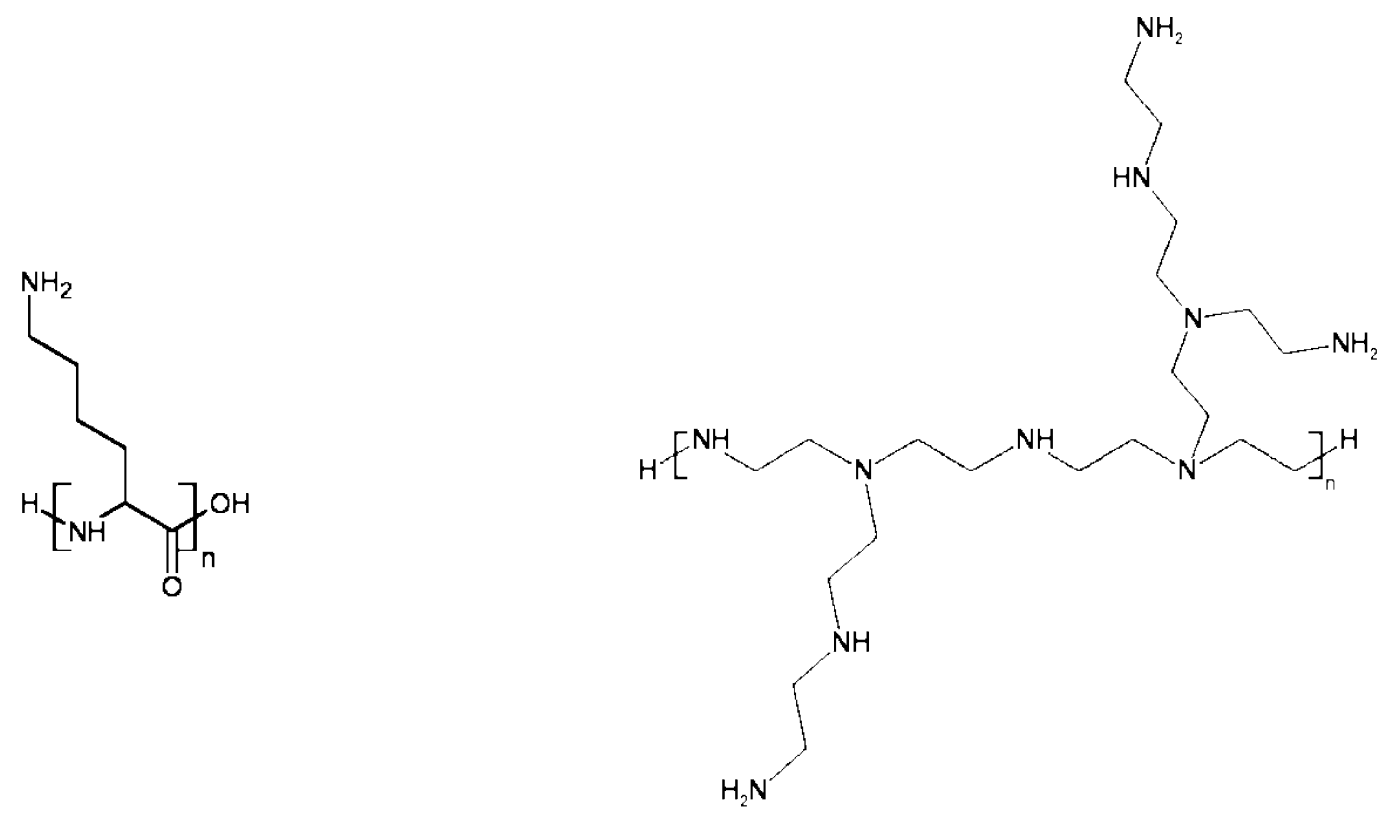

PLL

PEI<smiles>CCCCCCCC/C=C/CCCCCCCC(=O)OCC(CN)OC(=O)CCCCCCCCCCCCCC</smiles>

\section{DOTAP}<smiles>CCCCCCCCC=CCCCCCCCCCCCCC(=O)OCC(COP(=O)(O)OCCN)OC(=O)CCCCCCCCC</smiles>

\section{DOPE}

Fig. 1. Structures of common polymers and lipids used as nonviral gene vectors. Cationic polymers include poly (L-lysine) (PLL) and poly(ethylenimine) (PEI). 1,2-dioleoyl-3-trimethylammonium propane (DOTAP) is a cationic lipid and dioleoylphosphatidylethanolamine (DOPE) is a neutral "helper" lipid often included in cationic lipid formulations.

which employs Nucleofector Technology (developed by Amaxa Biosystems) has demonstrated impressive transfection efficiencies in primary neurons $(47,48)$. However, translation of this technique to in vivo applications is challenged by the need to apply an electrical field in close proximity to cells, as well as its lack of cell type specificity. Although it is generally accepted that nucleic acids require chemical and/or physical means to gain entry into cells, a few studies have demonstrated the ability of uncondensed, "naked" nucleic acids to mediate gene expression in neurons when administered in vivo. Notably, naked DNA has been shown to mediate reporter gene expression in the brain stem following either intramuscular injection in the tongue or intracisternal injection (49,50). Additionally, naked plasmid DNA has been shown to mediate low levels of reporter gene expression in neurons and astrocytes when delivered to sites of spinal cord 
injury (51). The mechanism by which naked DNA mediates transfection in the CNS warrants further investigation.

\section{In vivo Successes}

While a number of nonviral vectors, described in the previous section, have mediated reporter gene expression in the CNS of animal models, only a few of these systems have been successfully applied toward animal models of neurological disease or injury. Notably, several nonviral gene delivery approaches have been validated in animal models of Parkinson's disease. For example, Zhang et al. (11) showed that intravenous administration of PEGylated immunoliposomes mediated brain-specific delivery of a gene encoding tyrosine hydroxylase $(\mathrm{TH})$, resulting in reversal of motor impairment. Recently, polyplexes incorporating a plasmid encoding human GDNF as well as ligands for receptor targeting and intracellular trafficking were injected into the substantia nigra of hemiparkinsonian rats, resulting in therapeutic levels of GDNF expression and a reversal of motor impairment (10). These studies have validated nonviral delivery as a viable alternative for CNS gene therapy.

Additional studies have demonstrated the potential of nonviral vectors to mediate functional improvement in models of nerve and brain injury. For example, Barati et al. (52) delivered a plasmid encoding GDNF to injured nerves using a neurotrophin receptor-targeted, PLL-based polyplex and demonstrated an almost complete reversal in neuronal death caused by GDNF transgene expression. The expression of NGF in the dorsal root ganglia following intrathecal injection of PEI/DNA complexes has also led to regeneration of transected peripheral nerves (53). Finally, cationic lipid-based vectors targeted to transferrin receptors have been shown to ameliorate morphological damage in a model of brain injury through low levels of NGF expression in the striatum (54).

\section{Limitations of Current Technology}

While the in vivo successes with nonviral vectors to date are encouraging, improvements in nonviral formulations are critical before they can be broadly applied toward the treatment of neurological disease and injury. One issue that remains to be addressed is the relatively low transfection efficiency mediated by nonviral carriers compared to neurotropic viruses. Several of the disease conditions treated by nonviral delivery systems, described in the previous section, responded to very small amounts of the secreted transgenes GDNF or NGF. For diseases caused by either toxic gainof-function mutations or loss-of-function mutations that cannot be corrected by the introduction of secreted factors, more efficient nonviral vectors will be required.

Another important consideration is the duration of transgene expression afforded by nonviral delivery systems. Whereas PEI-mediated neuronal transfection results in expression lasting several days to several weeks $(26,55)$, select viral vectors have been shown to mediate transgene expression in neurons that lasts up to half a year $(56,57)$. One explanation for the relatively short duration of transgene expression following injection of PEI/DNA polyplexes into the brain is the toxicity associated with overloading cells with foreign DNA. To test this hypothesis, Lemkine et al. (58) injected various polyplex dosages into the brains of newborn mice and found a dosage optimum above which the duration of transgene expression was reduced. Additionally, it was demonstrated that co-delivery of a reporter gene with bcl$\mathrm{X}(\mathrm{L})$, an anti-apoptotic gene, significantly increased expression levels of both genes after 1 week, suggesting that high polyplex dosages lead to apoptosis.

Broader application of nonviral gene delivery toward additional models of neurodegenerative disease and injury, and its eventual translation into the clinic, awaits the development of formulations with improved transfection profiles. Future progress will depend on characterizing the physiological barriers encountered by nonviral carriers, systematically testing formulations, and integrating knowledge of the multiple barriers encountered into rationally designed nonviral gene carriers. As described in the subsequent sections, a thorough understanding of the intra- and extracellular barriers encountered by nonviral vectors may lead to the development of more effective delivery strategies.

\section{INTRACELLULAR BARRIERS ENCOUNTERED BY GENE CARRIERS IN NEURONS}

Neurons are a notoriously difficult cell type to transfect, both in vitro and in vivo $(59,60)$. This is due, in part, to the multiple biological barriers that vehicles must overcome in the intracellular milieu. The most challenging intracellular route is encountered by vectors delivered to the distal ends of neuronal projections. In order to successfully transfect neurons, vectors must bind to the neuronal cell surface, enter the neuron by endocytosis, and travel toward the nucleus (Fig. 2). Upon vesicular escape, vectors must mediate delivery of therapeutic cargo to the appropriate cellular compartment: the neuronal nucleus, for plasmid DNA encoding a therapeutic gene, or the perinuclear region of the cytoplasm, for siRNA. While numerous nonviral vectors have been developed and studied for their ability to deliver genetic material to neurons in culture and in vivo, few studies have investigated and characterized the intracellular barriers encountered by these vectors. The following sections detail each of the intracellular barriers potentially encountered by neuron-targeted nonviral vectors and describe efforts aimed at overcoming these barriers.

\section{Cell Targeting and Binding}

Association with the neuronal plasma membrane is required for internalization of vectors into the cell. While nonviral vectors can associate with most cell types via nonspecific binding to the cell surface, neuron-specific targeting strategies based on receptor-ligand interactions are preferable to prevent widespread delivery to off-target cells. Neurons express a number of different classes of receptors, including neuropeptide, neurotrophin, and neurotoxin receptors (summarized in Table 2). Targeting moieties corresponding to each of these classes of receptors have been tested in nonviral delivery systems. As an early example of a neuron-targeted polyplex, Martinez-Fong et al. conjugated neurotensin (NT), a 13-amino acid neuropeptide, to PLL, and demonstrated targeted uptake in cultured cells (61). In subsequent work, the delivery vector was improved by 

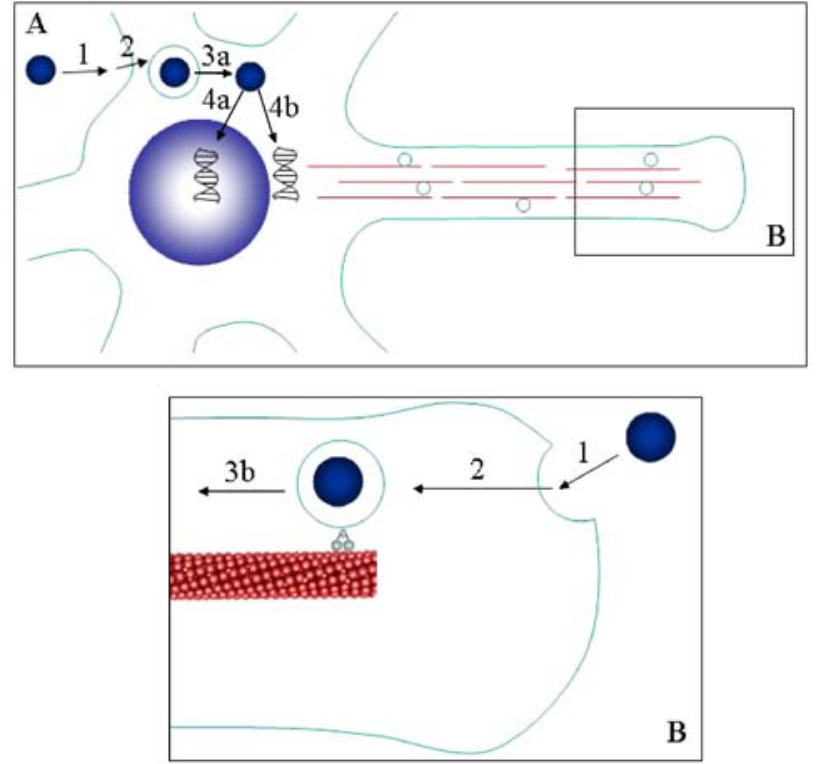

Fig. 2. A series of intracellular barriers is encountered by nonviral gene carriers in neurons. (A) Successful vehicles must be able to (1) associate with the neuronal plasma membrane, (2) undergo internalization, $(3 a)$ escape endosomes, and (4) deliver nucleic acids to the nucleus $(a)$ or cytoplasm $(b)$. (B) If vehicles arrive at the axon terminus, they must additionally undergo retrograde axonal transport $(3 b)$.

incorporation of the fusogenic peptide hemagglutinin HA2 and the Vp1 nuclear localization signal; these targeted gene carriers could be applied toward the treatment of Parkinson's disease, as the high-affinity neurotensin receptor is expressed predominantly in the nigrostriatal and mesolimbic dopaminergic systems (62).

Neurotrophin receptors are an attractive target for neuron-targeted polyplexes because they are expressed by specific neuron subtypes, including dorsal root ganglia, sympathetic neurons, and basal forebrain cholinergic neurons. Various strategies have been described for targeting polymer-based gene carriers to either TrkA or the $\mathrm{p} 75^{\mathrm{NTR}}$ receptors for NGF. Zeng et al. (63) formulated ternary complexes by electrostatic association of plasmid DNA, low molecular weight PEI, and the nerve growth factor loop 4 hairpin motif. These complexes mediated specific gene transfer into cultured cells expressing the TrkA receptor as well as into dorsal root ganglia in vivo, while minimizing the toxicity caused by nonspecific uptake of large amounts of higher-molecular weight PEI. In addition to targeting receptors expressed by specific neuronal populations, it would be ideal to target receptors whose upregulation corresponds to specific disease or injury states. To demonstrate this strategy, Barati et al. (52) conjugated an antibody that binds to the $\mathrm{p} 75^{\mathrm{NTR}}$ neurotrophin receptor (MC192) to PLL-based polyplexes and demonstrated transgene expression in targeted neurons in models of peripheral nerve injury.

As a final class of neuron-targeting ligands, neurotoxins have been exploited for their ability to efficiently hijack cellular internalization machinery as a means to invade targeted neurons. Of particular interest is tetanus toxin (TeNT), which undergoes efficient retrograde transport in motor neurons following internalization at presynaptic terminals. The purified, recombinant heavy chain fragment of TeNT (TTC), which is responsible for TeNT cell binding and retrograde axonal transport, has been conjugated to PLL as a means to direct polyplexes into cell lines expressing the relevant receptors (64). Recently, Liu et al. (65) identified a 12-amino acid peptide, Tet1, that mimics the receptor binding properties of TTC. Our group has conjugated this peptide to PEI and demonstrated specific uptake of Tet1-modified PEI/DNA polyplexes by cells expressing receptors for TTC (66).

These studies demonstrate that specific neuronal subpopulations can be targeted for transfection by ligandmodified polyplexes. Targeted delivery has the ability to improve the biodistribution of transgene expression caused by PEI-based vectors, since untargeted polyplexes have been shown to cause transfection of both neuronal and nonneuronal cell types in the CNS (26). Targeting studies with non-viral vectors have been facilitated by the ease with which primary amine-containing polymers, such as PEI and PLL, can be linked to targeting moieties via chemical conjugation. Although the transfection efficiencies mediated by neurontargeted, polymer-based carriers are limited compared to viruses, their advantage is in their cell-targeting specificity.

\section{Nonspecific Binding and Uptake}

In addition to receptor-mediated uptake, direct administration of cationic vectors to targeted cell populations can result in nonspecific cell association through interactions with anionic membrane proteins such as proteoglycans (67) (Fig. 3). This strategy has been employed for transfection of neurons in culture and in the CNS $(24,26,55)$. Understanding and predicting the efficiency of nonspecific neuronal uptake is complicated by the fact that neurons are a highly polarized cell type with somal, axonal, and dendritic domains having distinct membrane compositions $(68,69)$. Further, the physicochemical

Table 2. Neuron-Targeting Ligands and their Incorporation into Nonviral Vectors

\begin{tabular}{lcc}
\hline Ligand Class & Example Ligand & Neuronal Populations Targeted \\
\hline Neuropeptides & Neurotensin & $\begin{array}{c}\text { Nigrostriatal and mesolimbic } \\
\text { dopaminergic system } \\
\text { Dorsal root ganglia, sympathetic } \\
\text { seurotrophins }\end{array}$ \\
& Nerve growth factor (NGF) & Reurons, basal forebrain \\
cholinergic neurons & All peripheral neurons (autonomic, \\
meurotoxins & Tetanus toxin (TeNT) & and sensory)
\end{tabular}


characteristics of gene carriers, including the size, charge, and surface composition, may strongly influence the nature of their interaction with the neuronal plasma membrane. Additionally, the efficiency of cell binding and internalization is likely to depend on the cell type. Suk et al. (70) described reduced uptake of PEI/DNA complexes by differentiated, neuron-like cells as compared to undifferentiated cells. They speculated that this was due to a difference in heparan sulfate density on the surfaces of differentiated versus undifferentiated cells (71). We have also shown that binding and internalization of cationic lipid-based gene carriers is more efficient at neuronal soma than at neurites (72). Consequently, the efficiency of internalization of nonviral gene carriers may differ depending on the cell type, the delivery site, and the specific vehicle formulation.

\section{Vesicular Escape}

Regardless of the mechanism or location of entry, gene carriers that are internalized within neurons are typically sequestered in vesicles. Vesicles that are part of the endo-/ lysosomal pathway will acidify and eventually fuse with lysosomes in the neuronal soma to degrade their contents. Both polyplexes and lipoplexes delivered to neurite terminals of NGF-differentiated PC-12 cells undergo internalization within vesicles, demonstrated by co-localization of labeled vectors with fluid phase uptake markers (72). The poor ability of nonviral gene carriers to escape vesicles following internalization in neurons and their subsequent degradation in lysosomal compartments may explain their significantly reduced transfection efficiencies compared to viruses, which have been shown to efficiently escape vesicles in neurons (73).

Clearly, the design of improved nonviral gene carriers must incorporate elements that mediate vesicular escape prior to degradation of materials in endo-/lysosomal compartments. Strategies that promote endosomal escape include the use of PEI-based carriers, which are believed to buffer acidifying endosomes and mediate vesicular escape through osmotic swelling (known as the proton sponge effect), as well as the incorporation of peptides designed to disrupt the endosomal membrane $(25,74)$. For lipid-based carriers, the incorporation of DOPE can facilitate endosomal escape, as it undergoes a $\mathrm{pH}$-triggered phase transition which can lead to

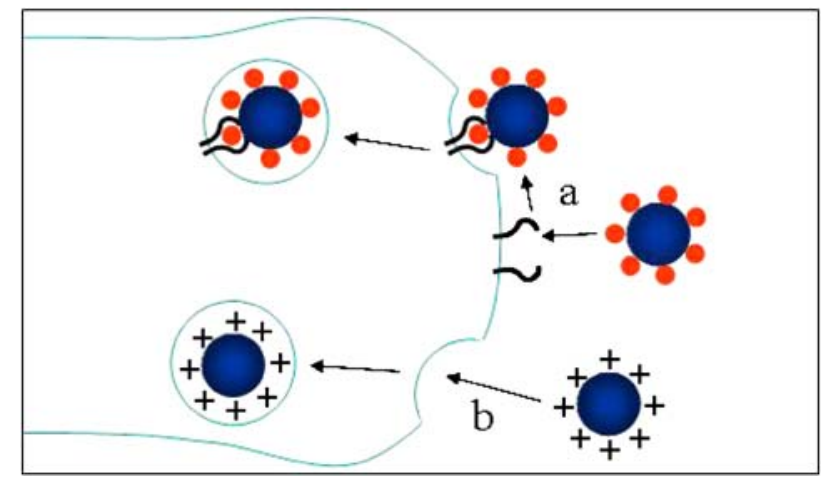

Fig. 3. The internalization of nonviral vectors can be accomplished specifically via receptor targeting $(a)$ or nonspecifically through electrostatic attractions between positively charged gene carriers and negatively charged groups on the neuronal plasma membrane $(b)$. endosomal membrane disruption (75). The location of vesicular escape is also important and may depend on the initial delivery site (soma versus neurites). While carriers internalized at cell soma may escape vesicles in close proximity to their ultimate subcellular destination, carriers that escape prematurely from axonal or dendritic vesicles face another challenge, efficient trafficking to cell soma.

\section{Retrograde Axonal Transport}

Retrograde transport of non-viral vectors following uptake into mammalian cells has been described, and several recent studies have investigated this process in neuronal cells (72,73,76). Wang et al. (55) demonstrated the capability of PEI/DNA complexes to undergo internalization within axon terminals in the tongue and retrograde transport back to neuronal soma in the brain stem. Using particle tracking, Suk et al. (73) directly observed the retrograde transport of labeled PEI/DNA complexes in live primary neurons. We have also analyzed retrograde transport of polyplexes following localized delivery to the distal ends of neurites in a microfluidic, compartmented culture model that mimics peripheral delivery (72). However, the movement observed in most systems is due to transport within endosomes, which are known to acidify and degrade their contents upon arrival at the microtubule-organizing center. In gene delivery systems that effectively bypass degradation by releasing their cargo from early endosomes, transport within the cytoplasm is likely to be a major rate-limiting step due to limited diffusion of particles $>30 \mathrm{~nm}$ in size (77). This is especially true for vectors that escape from vesicles within the axon (Fig. 4).

Cells have developed a highly complex transport infrastructure that conveys diffusion-limited cargo along cytoskeletal filaments. Microtubule-based transport is critical for neuronal function since it allows communication between the cell body and axon. For retrograde transport toward the nucleus, dynein is the primary minus end-directed motor (78, 79). Several viruses take advantage of this retrograde transport system for delivery of viral proteins and nucleic acids to the nucleus (80-84). Dynein-mediated transport is a critical process in the infection cycle of neurotropic viruses such as HSV and adenovirus (85). The fact that viral particles, which are similar in size to non-viral gene carriers, recruit the dynein motor for assisted retrograde transport validates the need to develop nonviral vectors that can also actively recruit the retrograde motor machinery for efficient delivery to neurons.

Despite the clear need for a retrograde transport moiety, linking artificial cargo to the dynein motor complex has proven challenging. The development of a dynein-binding moiety to facilitate retrograde transport of therapeutic cargo in cells has been proposed $(86,87)$, but a feasible method for the linkage of synthetic cargo to the dynein motor complex has not yet been demonstrated. Our group is developing strategies to overcome the limited diffusion of gene delivery nanoparticles by incorporating elements that actively recruit the dynein motor complex for retrograde intracellular transport (Fig. 5). We recently evaluated the ability of a peptide that binds the 8 -kDa light chain of the dynein motor complex (88), and are currently investigating peptides that bind to other light chain subunits. 


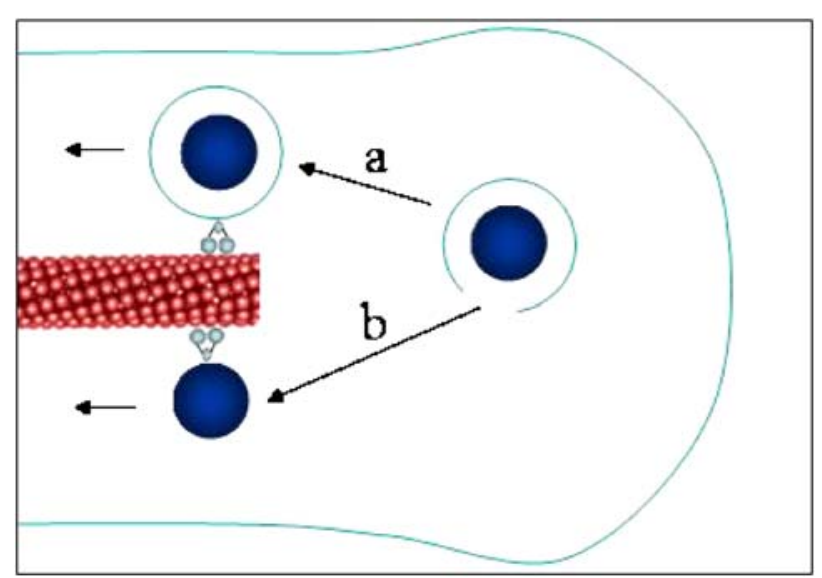

Fig. 4. Vehicles delivered to the distal ends of neurites must undergo active retrograde transport either inside of vesicles $(a)$ or through direct interaction with microtubule-based motor proteins $(b)$.

\section{Nuclear Entry}

Given the postmitotic nature of neurons, the nuclear import of therapeutic plasmid DNA is an important prerequisite for efficient transgene expression. There have been numerous attempts to incorporate nuclear localization signal (NLS) peptides into nonviral gene carriers as a means to promote nuclear import (reviewed recently by van der Aa et al. (89)). However, a consensus regarding how to most effectively incorporate NLS peptides into nonviral vehicles has not been reached. Furthermore, attempts to improve nonviral gene delivery to postmitotic cells by incorporating NLS peptides have resulted in modest increases in gene expression at best. Clearly, the ability of viruses to efficiently deliver genetic material into host cell nuclei has not yet been successfully reproduced in nonviral systems. Consequently, nuclear entry remains one of the most challenging barriers hindering the development of nonviral gene carriers in applications requiring delivery to postmitotic cells.

In contrast to plasmid delivery, the potential delivery of siRNA to neurons using nonviral carriers would not be hindered by the requirement for nuclear entry. Since the site of RNAi activity is hypothesized to be perinuclear (90), vectors that can efficiently deliver siRNA to the cell body should mediate successful gene knockdown. As several studies have recently demonstrated the ability of viruses to deliver DNA encoding shRNA to neurons, resulting in functional improvement in models of spinocerebellar ataxia, Huntington's disease, amyotrophic lateral sclerosis, and Alzheimer's disease (17-20), it is anticipated that nonviral carriers incorporating siRNA can also be applied toward a number of neurodegenerative disease conditions.

\section{Control of Gene Expression}

After gene carriers successfully deliver DNA to the host cell nucleus, the control of gene expression is critical to maintain the appropriate levels of therapeutic factors. While insufficient expression levels or durations can lead to suboptimal dosing of the therapeutic transgene, it can be equally detrimental to express too much transgene product. For example, high levels of NGF expression in the brain can cause sensory neurite ingrowth (91). Excessive or long-lasting expression of GDNF can lead to detrimental effects such as aberrant fiber sprouting and decreased dopamine production, minimizing functional recovery $(92,93)$. Consequently, for some applications, less efficient nonviral vectors may offer transgene expression levels within the optimal therapeutic window. Select nonviral vectors are also a viable option for treatment schemes requiring long-term expression. For example, Shi et al. demonstrated that repeated intrathecal administration of polyplexes formulated with PEG-grafted PEI resulted in prolonged transgene expression in the spinal cord (29). However, the design of vectors that transfect specific cell populations and which can be precisely regulated remains to be achieved.

Two approaches have been employed in nonviral systems for controlling transgene expression at the level of cell populations. First, the incorporation of neuron-specific promoters has been shown to limit gene expression to neuronal populations $(11,26)$. This strategy is useful when delivering formulations lacking cell-specific targeting ligands, as they have been shown to transfect cells in the CNS indiscriminately. However, since gene delivery materials can be toxic, it would be preferable to limit the internalization of material to targeted neuronal cells. Indeed, various strategies for targeting the delivery of nonviral gene carriers to specific cell populations through the display of specific targeting ligands have been explored and are described in previous sections of this article. As an additional measure, more precise control over expression levels once vectors have delivered DNA to targeted neuronal populations may benefit from plasmid engineering. Plasmid engineering strategies in nonviral gene therapy were recently reviewed by van Gaal et al. (94), and have the potential to improve the level and duration of transgene expression. We predict that nonviral vectors formulated with engineered plasmids susceptible to external regulation may provide a means to maintain protein expression levels within the therapeutic window.

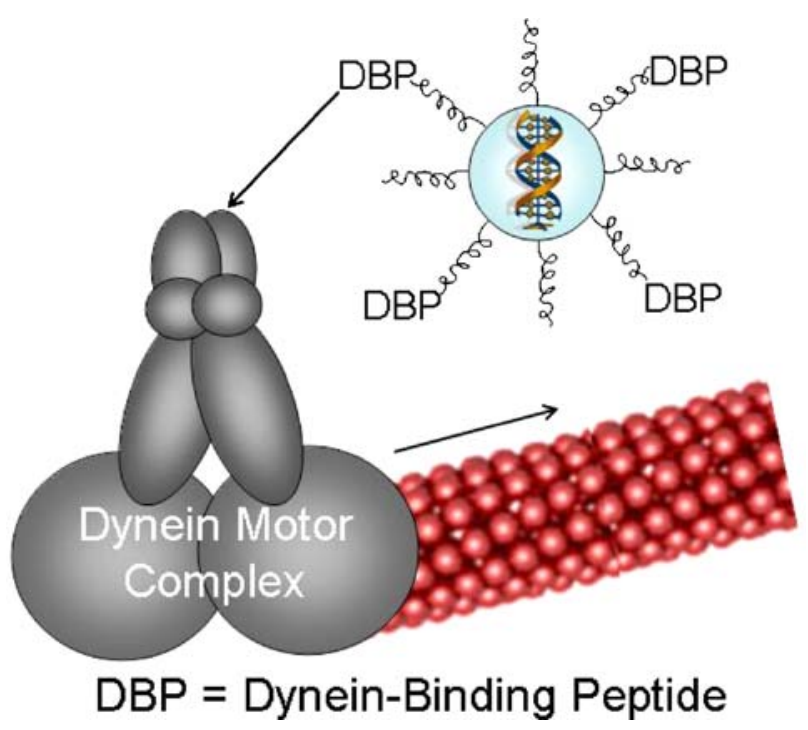

Fig. 5. Concept of a dynein-binding peptide. Synthetic gene carriers can be modified with dynein-binding peptides to mediate attachment to the dynein motor complex and active retrograde transport toward the neuronal nucleus. 


\section{EXTRACELLULAR BARRIERS OPPOSING NUCLEIC ACID DELIVERY TO THE CENTRAL NERVOUS SYSTEM}

The success of neuronal gene therapy is dependent on the accessibility of delivery vectors to targeted cells in the central nervous system (CNS). The central nervous system (CNS) plays a critical role in directing harmonious function to organs in the body. Therefore, the CNS is well-protected from the environment. A series of membranes called the meninges envelop the brain and spinal cord. These organs are further protected from physical injury by the skull and vertebrae, respectively. The CNS is also protected from passive access of blood-borne proteins, toxins or pathogens by the closely inter-connected capillary endothelial cells which form the blood-brain barrier (BBB) (95). These physical barriers of the CNS therefore also restrict access for most therapeutic interventions (96). Ideally, gene therapy strategies that target the CNS will result in efficient delivery to targeted neurons while avoiding invasive administration routes that could damage nervous tissue. Although neurotropic viruses such as herpes simplex virus have been used successfully in several animal models of CNS disease, nonviral gene therapy is largely hindered by inadequate methods of non-invasive delivery coupled with inefficient transgene expression of delivered materials. Therefore, the development of improved nonviral gene carriers will require a better understanding of the barriers encountered upon in vivo administration. The major administration routes for delivering nucleic acids to neurons in the CNS are illustrated in Fig. 6. Ultimately, the extracellular barriers encountered by gene carriers will depend on the route of administration, as summarized in the following sections.

\section{Direct Administration to the CNS}

\section{Intraparenchymal Direct Injection}

The neuronal populations affected by neurological disease may reside in a defined anatomical region of the brain. For example, Parkinson's disease is associated with degeneration of dopaminergic neurons in the substantia nigra (97) and Huntington's disease affects neurons in the striatum and neocortex (98). In such cases, delivery of therapeutic agents can be accomplished through localized administration methods. Intracranial direct injection is the simplest, but the most invasive, method employed for localized gene delivery to the brain. In this method, vectors are introduced inside or near the subpopulation of cells where the therapeutic outcome is required. Although invasive, this administration method is particularly viable for treatment of malignant brain tumors $(99,100)$, especially in cases when the administration of therapeutic genes can be performed in combination with surgical tumor resection. Additionally, direct injection of therapeutics can be performed in combination with the implantation of deep brain electrodes for the treatment of Parkinson's disease (101).

Intracranial injection has been used with varying degrees of success for introducing nonviral gene carriers to the CNS. Injection of naked DNA requires high doses and results in minimal gene expression, restricted expression areas, and non-specific expression in nearby glial cells and neurons (102). Attempts to improve transgene expression by physical bombardment of DNA-coated gold colloids resulted in astrocyte transfection because the uppermost layer of cerebrum reachable by gene gun delivery is comprised mainly of glial cells (103). Early studies with PEI established the feasibility of localized CNS gene delivery by direct brain injection into the cerebral cortex, hippocampus, and hypothalamus, resulting in transgene expression in neurons and glia (26). Since that pioneering work, targeted nonviral systems have been evaluated for more neuron-biased delivery $(10,104)$. For example, Martinez-Fong and colleagues recently demonstrated successful treatment in a rat model of Parkinson's disease by intranigral injection of neurotensinmodified PLL vectors encoding GDNF (10). Targeted lipoplexes and peptide-based delivery vectors have also been successfully administered via intracranial injection $(54,104)$.

The major drawbacks of direct intracranial injection are local trauma to the brain neuropil, inflammation and toxicity, as well as limited diffusion of vectors from the injection site. Indeed, intrastriatal injection of liposomes encapsulating a reporter gene resulted in local expression only in the area immediately surrounding the injection site (105). There have been several attempts using mathematical modeling to predict the distribution of drugs delivered by local injection into the brain (106). This information would be important in designing new drug delivery technologies for the CNS. A finite element model was developed based on transport of magnetic resonance imaging markers tracked in brain and used to predict transport of interleukin-2 in brain (107). However, more precise consideration of the properties of nanoparticles is required for better prediction of nonviral gene delivery due to their larger size and natural heterogeneity in physicochemical properties.

\section{Convection-Enhanced Delivery}

The limited diffusion of vectors following direct injection into the brain parenchyma can be alleviated by exploiting convective flow in the brain (108). Pressure gradients generated by convection-enhanced delivery (CED) increase interstitial flow, which in turn facilitate effective delivery of therapeutics throughout the brain with little physical or functional damage (100). Mechanistic studies have demonstrated that the CED-based approach is associated with perivascular transport in the brain, which is generated by arterial pulsation (109-111). The distribution of drugs delivered to the brain by CED is affected by infusion volume, rate, and cannula size, but is not influenced by the molecular weight, diffusivity, or concentration of the infusate (112). Therefore, it is likely that CED can achieve a wider distribution of nanoparticles like polyplexes or lipoplexes in the brain.

The improved distribution of liposomes delivered by CED has been verified by magnetic resonance imaging (MRI) (113). In contrast to diffusion-limited distributions observed from single, low-pressure injections, liposomes administered by CED were shown to infiltrate large areas of nervous tissue. A systematic characterization has been completed to determine the effect of osmolarity of buffer as well as size and surface properties of model polystyrene 

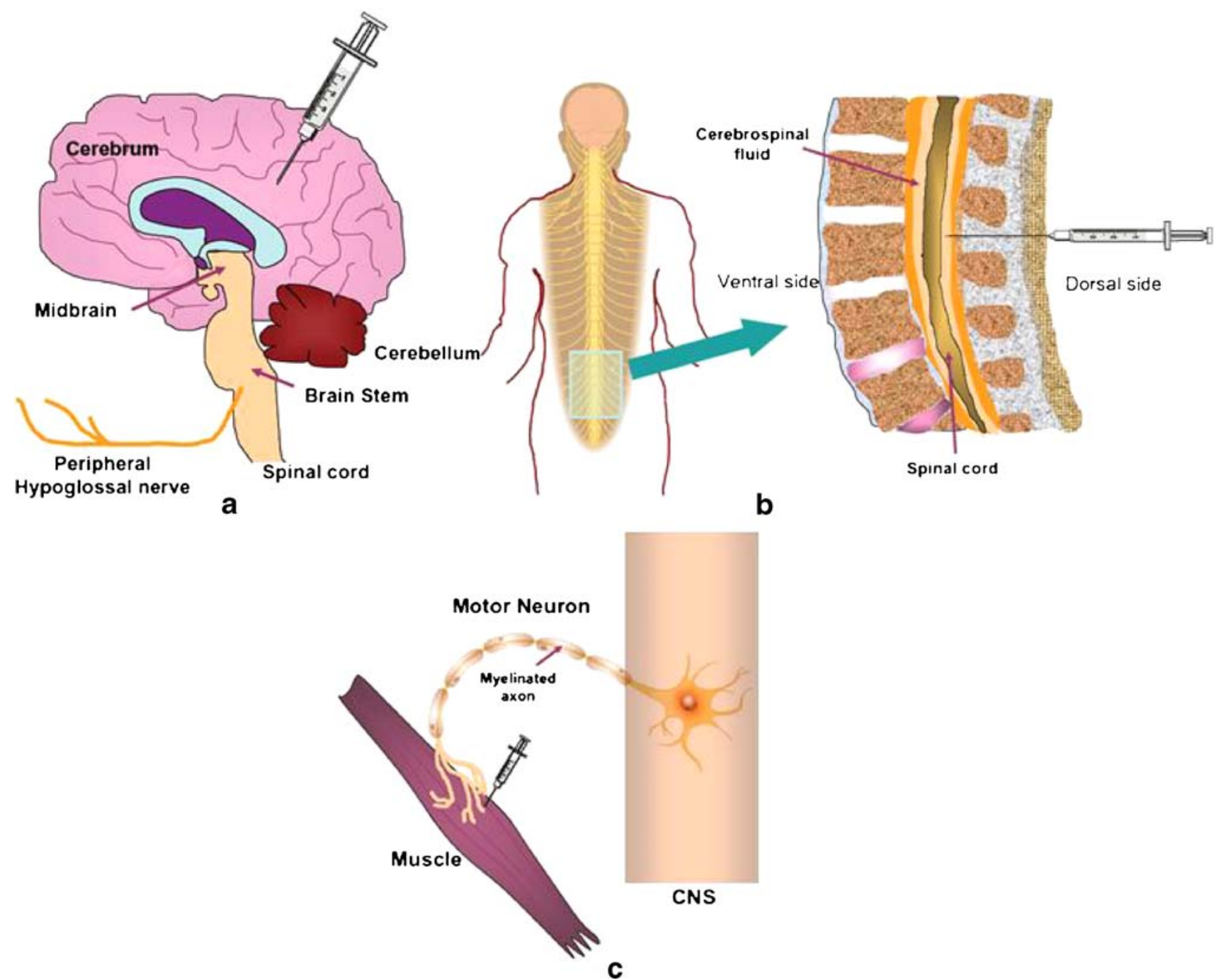

Fig. 6. Representative administration routes for neuronal gene delivery in vivo: intraparenchymal injection (a), intrathecal injection (b), intramuscular injection (c).

nanosphere, liposome, and nano-sized viral gene carriers like adeno-associated viruses and adenoviruses on distribution in CNS $(111,114)$. Nonspecific binding was found to be a major limitation in broad tissue distribution, even when vectors were administered by CED. Mathematical modeling of CED demonstrated that positively charged liposomes have 50-fold stronger binding affinity toward surrounding tissue than neutral liposomes, resulting in suboptimal particle penetration into tissue. To address this issue, a wider distribution can be achieved by coating nanospheres with anionic albumin or by modifying the surface of cationic liposomes with poly (ethylene glycol) (111).

Several variations of conventional CED have been recently explored. Microfluidics-mediated CED has been developed to reduce the tissue damage and backflow associated with injection needles or cannulae used for CED (115). An innovative application of CED was recently described to direct systemically-delivered materials to the CNS (116). A microdialysis catheter was used to create a local osmotic gradient, which facilitated extravasation of macromolecules through the blood-brain barrier. This method, termed retro-CED (R-CED), caused extravasation of systemically delivered liposomes into tumor tissue in the brain, suggesting that R-CED might be useful to improve drug efficacy for anti-tumor therapy.

\section{Intraventricular Injection}

While intracerebral injection is appropriate for therapeutic interventions that require gene expression in specific regions of the brain, alternative administration methods are necessary to achieve a more global distribution of vectors or gene products throughout the CNS. Intraventricular injection involves introduction of therapeutic agents into the cerebro- 
spinal fluid (CSF) produced in the ventricles of the brain. Using this method, vectors can distribute to cells lining the ventricular and subarachnoid space. Gene products secreted by these cells, such as growth factors, angiogenesis factors, and nitric oxide synthase (NOS) can ideally be released into the CSF and circulate through the brain for maximal efficacy (117).

In one example of intraventricular delivery, lipoplexes containing a reporter gene or heat shock protein HSP70 were infused into the lateral ventricle. Stereological analysis of gene expression after coronal sectioning demonstrated a longitudinal distribution of transgene expression, including expression in neurons as determined by cell morphology and adjacent section staining with NeuN antibodies $(118,119)$. The administration of neurotrophins such as nerve growth factor (NGF), brain-derived neurotrophic factor (BDNF), neurotrophin-3 (NT-3), neurotrophin-4 (NT-4) has been extensively used to treat CNS injury and disease $(54,120)$. As an alternative gene-based approach, lipoplexes encoding NGF were administered by intraventricular injection in a model of traumatic brain injury. Secretion of NGF into the CSF resulted in recovery of choline acetyltransferase function in cholinergic neurons (121). It should be noted, however, that genes delivered by lipoplexes are typically expressed in both neurons and glial cells near the injection site.

\section{Intrathecal Injection}

Intrathecal injection, delivery of materials to the intrathecal space surrounding the spinal cord, is an alternative fluid-phase delivery route to the CNS (122). Intrathecal administration causes minimal pain to patients and affords larger volume of therapeutic materials than intracranial injection. In contrast to intracranial injection, intrathecal injection of nanoparticles results in significantly more widespread distribution throughout the CNS (105). The Wang group has demonstrated gene delivery to neurons in the CNS by intrathecal injection of polyplexes composed of PEI and its derivatives $(28,29,41,53,123)$. Intrathecal delivery of PEI polyplexes resulted in transgene expression in neurons of the dorsal root ganglia at levels comparable to those achievable using baculovirus or adeno-associated virus. Transfection could be further improved by the addition of targeting ligands or by PEGylation to reduce particle size $(53,113)$. In addition, biodegradable vectors introduced by intrathecal injection have also mediated transgene delivery to neurons (50).

\section{Peripheral Administration for Neuron Delivery}

As an alternative to direct CNS injection, delivery vectors could hypothetically be administered peripherally and routed to the CNS post-injection. Peripheral administration, including intramuscular and intravenous injection, offers the advantages of safer and less invasive delivery as well as the possibility of larger injection volumes and multiple dosages. However, the therapeutic effect achievable by these approaches has been greatly limited due restricted access to the CNS as well as high systemic clearance of vectors.

\section{Intramuscular Injection}

Intramuscular (IM) injection is an attractive administration route for nonviral gene carriers because retrograde transport along motor neurons could (1) utilize a minimally invasive way to introduce foreign genes into the CNS and (2) circumvent the blood-brain barrier (BBB). Proof-of-concept studies involving tongue injection of polyplexes have shown retrograde transport of carriers, resulting in gene expression in the brain stem (55). To enhance the efficiency of retrograde transport of gene carriers in long-range motor neurons, several groups have investigated vectors derivatized with retrogradely transported proteins such as tetanus toxin C or various neurotrophic factors $(40,124)$. The non-toxic fragment $\mathrm{C}$ of tetanus toxin (TTC) has been reported to bind to axon terninals at the neuromuscular junction and undergo efficient retrograde transport (125). GDNF and brain-derived neurotrophic factor (BDNF) have also been shown to be retrogradely transported in motor neurons, similar to tetanus toxin (126); these proteins therefore are also potential ligand candidates for retrograde transport. An interesting approach utilized PLL conjugated to the monoclonal antibody (MC192) against neurotrophic receptor, $\mathrm{p} 75^{\mathrm{NTR}}$, for receptor-mediated retrograde transport (52). The polyplexes were delivery by injection into the hind limb of newborn rats or by placing a gel foam formulation on a transected hypoglossal nerve in adult rats. Transgene expression of GDNF was detected in both methods, and resulted in rescue of injured neurons.

Thus, intramuscular delivery of polyplex via retrogradely transported carriers in motor neurons is a promising approach to minimally invasive gene delivery. However, most assessments have utilized hind limb injection in newborn animals or tongue injection. Ultimately, demonstration of peripheral delivery from a more distal site and to neurons with fully developed synapses is important for clinically relevant demonstration of this technology. Finally, it is important to consider that, in some neurodegenerative diseases, impaired retrograde transport is a hallmark of the disease pathology (127). In such cases, direct CNS delivery is required to reach targeted neurons.

\section{Intravenous Injection}

There is an increasing demand for effective delivery strategies for the brain because advances in pharmaceutical technology have resulted in treatment opportunities for neurological diseases. Intravenous (IV) delivery is a wellestablished approach to introduce drugs or therapeutic genetic materials throughout the body since this route has minimal limitations on administration dose and accommodates repeated administration (128). For these applications, nonviral vectors offer the potential advantage over viral vectors of avoiding an immune response. However, nonviral gene carriers administered intravenously must overcome several obstacles before successfully reaching the brain. Interaction with serum proteins in the blood circulation compromises targeting and therapeutic efficacy of nonviral gene carriers by eclipsing targeting ligands or mediating opsonization and clearance from the circulation. Moreover, aggregation of vectors in the bloodstream can result in 
embolism in the capillary beds of the lung. Tethering hydrophilic groups such as dextran, PEG, or poly(vinyl pyrrolidone) to nanoparticles helps prevent non-specific binding with serum proteins and resulting aggregation (129).

The BBB, consisting of endothelial cells connected by tight junctions in the brain capillaries, poses a formidable challenge against the effective delivery of therapeutic genes to the CNS by severely limiting extravasation of delivery vectors $(99,130-132)$. The tight-junctions between endothelial cells and the physical and molecular barriers of the adjacent pericytes and astrocytic endfeet can be temporarily permeabilized by utilizing osmotic disruption with intracarotid hypertonic mannitol (133) or vasoactive compounds $(134,135)$. However, the safety of this approach has been raised as a concern because BBB disruption may cause brain toxicity due to leaking plasma proteins, thus potentially causing pathological changes (136-138).

Receptor-mediated transcytosis (RMT) has been investigated as an alternative strategy for crossing the BBB. Brainspecific systemic delivery systems based on antibody- and PEGconjugated liposomes, called PEGylated immunoliposomes (PIL), has been extensively explored by the Pardridge group (139-142). The monoclonal antibodies employed target receptors on the brain endothelial cells such as transferrin or the insulin receptor. Brain-specific expression has been mediated by PILs following IV injection (141). In another promising study, intravenous delivery of a tyrosine hydroxylase $(\mathrm{TH})$ expressing plasmid formulated with transferrin-targeted PILs normalized $\mathrm{TH}$ protein levels in the striatum and alleviated motor impairment in a rat model of Parkinson's disease (39).

\section{CONCLUSIONS}

Considering the numerous barriers encountered in applications of neuron-targeted nucleic acid delivery, the design of effective nonviral vehicles will require an integrated approach that accounts for each of the barriers. Understanding of the barriers encountered by nonviral vectors may inspire the design of improved nonviral vectors that can be tailored to specific applications of neuronal nucleic acid delivery. Ultimately, we envision the design of a multicomponent vector that remains stable upon in vivo administration, which incorporates functionalities for neuron targeting, endosomal escape, retrograde transport, and subcellular localization, and which can be tailored toward specific CNS-targeted delivery applications.

\section{ACKNOWLEDGMENTS}

This work was supported by an NIH/NINDS grant (5R21NS052030-02) and an NSF CAREER Award to SHP (BES 0454324). JMB acknowledges the Whitaker Foundation and the University of Washington's Engineered Biomaterials Training Program for support.

\section{REFERENCES}

1. W. J. Bowers, D. F. Howard, and H. J. Federoff. Gene therapeutic strategies for neuroprotection: implications for Parkinson's disease. Exp. Neurol. 144:58-68 (1997).
2. B. Blits, and M. B. Bunge. Direct gene therapy for repair of the spinal cord. J. Neurotrauma. 23:508-520 (2006).

3. J. M. Alisky, and B. L. Davidson. Gene therapy for amyotrophic lateral sclerosis and other motor neuron diseases. Hum. Gene. Ther. 11:2315-2329 (2000).

4. R. Tinsley, and P. Eriksson. Use of gene therapy in central nervous system repair. Acta. Neurol. Scand. 109:1-8 (2004).

5. T. Federici, and N. M. Boulis. Gene-based treatment of motor neuron diseases. Muscle Nerve. 33:302-323 (2006).

6. B. K. Kaspar, J. Llado, N. Sherkat, J. D. Rothstein, and F. H. Gage. Retrograde viral delivery of IGF-1 prolongs survival in a mouse ALS model. Science. 301:839-842 (2003).

7. A. P. Kells, D. M. Fong, M. Dragunow, M. J. During, D. Young, and B. Connor. AAV-mediated gene delivery of BDNF or GDNF is neuroprotective in a model of Huntington disease. Mol. Ther. 9:682-688 (2004).

8. R. J. Mandel, S. K. Spratt, R. O. Snyder, and S. E. Leff. Midbrain injection of recombinant adeno-associated virus encoding rat glial cell line-derived neurotrophic factor protects nigral neurons in a progressive 6-hydroxydopamine-induced degeneration model of Parkinson's disease in rats. Proc. Natl. Acad. Sci. U S A. 94:14083-14088 (1997).

9. D. L. Choi-Lundberg, Q. Lin, T. Schallert, D. Crippens, B. L. Davidson, Y. N. Chang, Y. L. Chiang, J. Qian, L. Bardwaj, and M. C. Bohn. Behavioral and cellular protection of rat dopaminergic neurons by an adenoviral vector encoding glial cell linederived neurotrophic factor. Exp. Neurol. 154:261-275 (1998).

10. J. A. Gonzalez-Barrios, M. Lindahl, M. J. Bannon, V. AnayaMartinez, G. Flores, I. Navarro-Quiroga, L. E. Trudeau, J. Aceves, D. B. Martinez-Arguelles, R. Garcia-Villegas, I. Jimenez, J. Segovia, and D. Martinez-Fong. Neurotensin polyplex as an efficient carrier for delivering the human GDNF gene into nigral dopamine neurons of hemiparkinsonian rats. Mol. Ther. 14:857-865 (2006).

11. Y. Zhang, F. Schlachetzki, Y. F. Zhang, R. J. Boado, and W. M. Pardridge. Normalization of striatal tyrosine hydroxylase and reversal of motor impairment in experimental parkinsonism with intravenous nonviral gene therapy and a brain-specific promoter. Hum. Gene. Ther. 15:339-350 (2004).

12. M. J. During, J. R. Naegele, K. L. O'Malley, and A. I. Geller. Longterm behavioral recovery in parkinsonian rats by an HSV vector expressing tyrosine hydroxylase. Science. 266:1399-1403 (1994).

13. C. S. Hong, W. F. Goins, J. R. Goss, E. A. Burton, and J. C. Glorioso. Herpes simplex virus RNAi and neprilysin gene transfer vectors reduce accumulation of Alzheimer's diseaserelated amyloid-beta peptide in vivo. Gene. Ther. 13:1068-1079 (2006).

14. B. L. Davidson, and H. L. Paulson. Molecular medicine for the brain: silencing of disease genes with RNA interference. Lancet. Neurol. 3:145-149 (2004).

15. E. Rodriguez-Lebron, and P. Gonzalez-Alegre. Silencing neurodegenerative disease: bringing RNA interference to the clinic. Expert. Rev. Neurother. 6:223-233 (2006).

16. A. Forte, M. Cipollaro, A. Cascino, and U. Galderisi. Small interfering RNAs and antisense oligonucleotides for treatment of neurological diseases. Curr. Drug. Targets. 6:21-29 (2005).

17. H. Xia, Q. Mao, S. L. Eliason, S. Q. Harper, I. H. Martins, H. T. Orr, H. L. Paulson, L. Yang, R. M. Kotin, and B. L. Davidson. RNAi suppresses polyglutamine-induced neurodegeneration in a model of spinocerebellar ataxia. Nat. Med. 10:816-820 (2004).

18. S. Q. Harper, P. D. Staber, X. He, S. L. Eliason, I. H. Martins, Q. Mao, L. Yang, R. M. Kotin, H. L. Paulson, and B. L. Davidson. RNA interference improves motor and neuropathological abnormalities in a Huntington's disease mouse model. Proc. Natl. Acad. Sci. U S A. 102:5820-5825 (2005).

19. G. S. Ralph, P. A. Radcliffe, D. M. Day, J. M. Carthy, M. A. Leroux, D. C. Lee, L. F. Wong, L. G. Bilsland, L. Greensmith, S. M. Kingsman, K. A. Mitrophanous, N. D. Mazarakis, and M. Azzouz. Silencing mutant SOD1 using RNAi protects against neurodegeneration and extends survival in an ALS model. Nat. Med. 11:429-433 (2005).

20. O. Singer, R. A. Marr, E. Rockenstein, L. Crews, N. G. Coufal, F. H. Gage, I. M. Verma, and E. Masliah. Targeting BACE1 
with siRNAs ameliorates Alzheimer disease neuropathology in a transgenic model. Nat. Neurosci. 8:1343-1349 (2005).

21. R. A. Dewey, G. Morrissey, C. M. Cowsill, D. Stone, F. Bolognani, N. J. Dodd, T. D. Southgate, D. Klatzmann, H. Lassmann, M. G. Castro, and P. R. Lowenstein. Chr]onic brain inflammation and persistent herpes simplex virus 1 thymidine kinase expression in survivors of syngeneic glioma treated by adenovirus-mediated gene therapy: implications for clinical trials. Nat. Med. 5:1256-1263 (1999).

22. C. S. Peden, C. Burger, N. Muzyczka, and R. J. Mandel. Circulating anti-wild-type adeno-associated virus type 2 (AAV2) antibodies inhibit recombinant AAV2 (rAAV2)mediated, but not rAAV5-mediated, gene transfer in the brain. J. Virol. 78:6344-6359 (2004).

23. D. W. Pack, A. S. Hoffman, S. Pun, and P. S. Stayton. Design and development of polymers for gene delivery. Nat. Rev. Drug. Discov. 4:581-593 (2005).

24. O. Boussif, F. Lezoualc'h, M. A. Zanta, M. D. Mergny, D. Scherman, B. Demeneix, and J. P. Behr. A versatile vector for gene and oligonucleotide transfer into cells in culture and in vivo: polyethylenimine. Proc. Natl. Acad. Sci. U S A. 92:72977301 (1995).

25. N. D. Sonawane, F. C. Szoka, Jr., and A. S. Verkman. Chloride accumulation and swelling in endosomes enhances DNA transfer by polyamine-DNA polyplexes. J. Biol. Chem. 278:44826-44831 (2003).

26. B. Abdallah, A. Hassan, C. Benoist, D. Goula, J. P. Behr, and B. A. Demeneix. A powerful nonviral vector for in vivo gene transfer into the adult mammalian brain: polyethylenimine. Hum. Gene. Ther. 7:1947-1954 (1996).

27. M. Berry, L. Barrett, L. Seymour, A. Baird, and A. Logan. Gene therapy for central nervous system repair. Curr. Opin. Mol. Ther. 3:338-349 (2001).

28. G. P. Tang, J. M. Zeng, S. J. Gao, Y. X. Ma, L. Shi, Y. Li, H. P. Too, and S. Wang. Polyethylene glycol modified polyethylenimine for improved CNS gene transfer: effects of PEGylation extent. Biomaterials. 24:2351-2362 (2003).

29. L. Shi, G. P. Tang, S. J. Gao, Y. X. Ma, B. H. Liu, Y. Li, J. M. Zeng, Y. K. Ng, K. W. Leong, and S. Wang. Repeated intrathecal administration of plasmid DNA complexed with polyethylene glycol-grafted polyethylenimine led to prolonged transgene expression in the spinal cord. Gene. Ther. 10:11791188 (2003).

30. L. Wasungu, and D. Hoekstra. Cationic lipids, lipoplexes and intracellular delivery of genes. J. Control. Release. 116:255-264 (2006).

31. S. Kaech, J. B. Kim, M. Cariola, and E. Ralston. Improved lipid-mediated gene transfer into primary cultures of hippocampal neurons. Brain. Res. Mol. Brain. Res. 35:344348 (1996).

32. B. Wiesenhofer, and C. Humpel. Lipid-mediated gene transfer into primary neurons using FuGene: comparison to C6 glioma cells and primary glia. Exp. Neurol. 164:38-44 (2000).

33. M. T. da Cruz, S. Simoes, and M. C. de Lima. Improving lipoplex-mediated gene transfer into C6 glioma cells and primary neurons. Exp. Neurol. 187:65-75 (2004).

34. E. C. Ohki, M. L. Tilkins, V. C. Ciccarone, and P. J. Price. Improving the transfection efficiency of post-mitotic neurons. J. Neurosci. Methods. 112:95-99 (2001).

35. S. Li, W. C. Tseng, D. B. Stolz, S. P. Wu, S. C. Watkins, and L. Huang. Dynamic changes in the characteristics of cationic lipidic vectors after exposure to mouse serum: implications for intravenous lipofection. Gene. Ther. 6:585-594 (1999).

36. W. M. Pardridge. Drug and gene targeting to the brain with molecular Trojan horses. Nat. Rev. Drug. Discov. 1:131-139 (2002).

37. N. Shi, and W. M. Pardridge. Noninvasive gene targeting to the brain. Proc. Natl. Acad. Sci. U S A. 97:7567-7572 (2000).

38. Y. Zhang, C. Zhu, and W. M. Pardridge. Antisense gene therapy of brain cancer with an artificial virus gene delivery system. Mol. Ther. 6:67-72 (2002).

39. Y. Zhang, F. Calon, C. Zhu, R. J. Boado, and W. M. Pardridge. Intravenous nonviral gene therapy causes normalization of striatal tyrosine hydroxylase and reversal of motor impairment in experimental parkinsonism. Hum. Gene. Ther. 14:1-12 (2003).
40. S. Barati, F. Chegini, P. Hurtado, and R. A. Rush. Hybrid tetanus toxin $\mathrm{C}$ fragment-diphtheria toxin translocation domain allows specific gene transfer into PC12 cells. Exp. Neurol. 177:75-87 (2002).

41. N. Ma, S. S. Wu, Y. X. Ma, X. Wang, J. Zeng, G. Tong, Y. Huang, and S. Wang. Nerve growth factor receptor-mediated gene transfer. Mol. Ther. 9:270-281 (2004).

42. J. Zeng, H. P. Too, Y. Ma, E. S. Luo, and S. Wang. A synthetic peptide containing loop 4 of nerve growth factor for targeted gene delivery. J. Gene. Med. 6:1247-1256 (2004).

43. J. Zeng, and S. Wang. Enhanced gene delivery to PC12 cells by a cationic polypeptide. Biomaterials. 26:679-686 (2005).

44. Y. M. Usachev, A. Khammanivong, C. Campbell, and S. A. Thayer. Particle-mediated gene transfer to rat neurons in primary culture. Pflugers. Arch. 439:730-738 (2000).

45. J. J. Xiang, J. Q. Tang, S. G. Zhu, X. M. Nie, H. B. Lu, S. R. Shen, X. L. Li, K. Tang, M. Zhou, and G. Y. Li. IONP-PLL: a novel non-viral vector for efficient gene delivery. J. Gene. Med. 5:803-817 (2003).

46. D. J. Bharali, I. Klejbor, E. K. Stachowiak, P. Dutta, I. Roy, N. Kaur, E. J. Bergey, P. N. Prasad, and M. K. Stachowiak. Organically modified silica nanoparticles: a nonviral vector for in vivo gene delivery and expression in the brain. Proc. Natl. Acad. Sci. U S A. 102:11539-11544 (2005).

47. A. Gartner, L. Collin, and G. Lalli. Nucleofection of primary neurons. Methods Enzymol. 406:374-388 (2006).

48. P. G. Leclere, A. Panjwani, R. Docherty, M. Berry, J. Pizzey, and D. A. Tonge. Effective gene delivery to adult neurons by a modified form of electroporation. J. Neurosci. Methods. 142:137-143 (2005).

49. R. Morris, B. S. Morgan, T. M. Lewis, K. D. Pierce, A. Pisano, and P. R. Schofield. In vivo somatic delivery of plasmid DNA and retrograde transport to obtain cell-specific gene expression in the central nervous system. J. Neurochem. 90:1445-1452 (2004).

50. Y. Li, J. Wang, C. G. Lee, C. Y. Wang, S. J. Gao, G. P. Tang, Y. X. Ma, H. Yu, H. Q. Mao, K. W. Leong, and S. Wang. CNS gene transfer mediated by a novel controlled release system based on DNA complexes of degradable polycation PPE-EA: a comparison with polyethylenimine/DNA complexes. Gene Ther. 11:109-114 (2004).

51. B. H. Choi, Y. Ha, C. H. Ahn, X. Huang, J. M. Kim, S. R. Park, H. Park, H. C. Park, S. W. Kim, and M. Lee. A hypoxiainducible gene expression system using erythropoietin $3^{\prime}$ untranslated region for the gene therapy of rat spinal cord injury. Neurosci. Lett. 412:118-122 (2007).

52. S. Barati, P. R. Hurtado, S. H. Zhang, R. Tinsley, I. A Ferguson, and R. A. Rush. GDNF gene delivery via the p75(NTR) receptor rescues injured motor neurons. Exp. Neurol. 202:179-188 (2006).

53. X. Wang, C. Wang, J. Zeng, X. Xu, P. Y. Hwang, W. C. Yee, Y. K $\mathrm{Ng}$, and S. Wang. Gene transfer to dorsal root ganglia by intrathecal injection: effects on regeneration of peripheral nerves. Mol. Ther. 12:314-320 (2005).

54. M. T. da Cruz, A. L. Cardoso, L. P. de Almeida, S. Simoes, and M. C. de Lima. Tf-lipoplex-mediated NGF gene transfer to the CNS: neuronal protection and recovery in an excitotoxic model of brain injury. Gene. Ther. 12:1242-1252 (2005).

55. S. Wang, N. Ma, S. J. Gao, H. Yu, and K. W. Leong. Transgene expression in the brain stem effected by intramuscular injection of polyethylenimine/DNA complexes. Mol. Ther. 3:658-664 (2001).

56. F. Finiels, M. Gimenez y Ribotta, M. Barkats, M. L. Samolyk, J. J. Robert, A. Privat, F. Revah, and J. Mallet. Specific and efficient gene transfer strategy offers new potentialities for the treatment of motor neurone diseases. Neuroreport. 7:373-378 (1995).

57. J. Yamamura, S. Kageyama, T. Uwano, M. Kurokawa, M. Imakita, and K. Shiraki. Long-term gene expression in the anterior horn motor neurons after intramuscular inoculation of a live herpes simplex virus vector. Gene. Ther. 7:934-941 (2000).

58. G. F. Lemkine, D. Goula, N. Becker, L. Paleari, G. Levi, and B. A. Demeneix. Optimisation of polyethylenimine-based gene delivery to mouse brain. J. Drug. Target. 7:305-312 (1999). 
59. P. Washbourne, and A. K. McAllister. Techniques for gene transfer into neurons. Curr. Opin. Neurobiol. 12:566-573 (2002).

60. E. H. Lo, A. B. Singhal, V. P. Torchilin, and N. J. Abbott. Drug delivery to damaged brain. Brain. Res. Brain. Res. Rev. 38:140148 (2001).

61. D. Martinez-Fong, I. Navarro-Quiroga, I. Ochoa, I. AlvarezMaya, M. A. Meraz, J. Luna, and J. A. Arias-Montano. Neurotensin-SPDP-poly-L-lysine conjugate: a nonviral vector for targeted gene delivery to neural cells. Brain. Res. Mol. Brain. Res. 69:249-262 (1999).

62. I. Navarro-Quiroga, J. Antonio Gonzalez-Barrios, F. BarronMoreno, V. Gonzalez-Bernal, D. B. Martinez-Arguelles, and D. Martinez-Fong. Improved neurotensin-vector-mediated gene transfer by the coupling of hemagglutinin HA2 fusogenic peptide and Vp1 SV40 nuclear localization signal. Brain. Res. Mol. Brain. Res. 105:86-97 (2002).

63. J. Zeng, X. Wang, and S. Wang. Self-assembled ternary complexes of plasmid DNA, low molecular weight polyethylenimine and targeting peptide for nonviral gene delivery into neurons. Biomaterials. 28:1443-1451 (2007).

64. A. Knight, J. Carvajal, H. Schneider, C. Coutelle, S. Chamberlain, and N. Fairweather. Non-viral neuronal gene delivery mediated by the HC fragment of tetanus toxin. Eur. J. Biochem. 259:762-769 (1999).

65. J. K. Liu, Q. Teng, M. Garrity-Moses, T. Federici, D. Tanase, M. J. Imperiale, and N. M. Boulis. A novel peptide defined through phage display for therapeutic protein and vector neuronal targeting. Neurobiol. Dis. 19:407-418 (2005).

66. I. K. Park, J. Lasiene, S. Chou, P. J. Horner, and S. H. Pun. Neuron-specific delivery of nucleic acids mediated by Tet1modified poly(ethylenimine). J. Gene Med. 9:691-702 (2007).

67. K. A. Mislick, and J. D. Baldeschwieler. Evidence for the role of proteoglycans in cation-mediated gene transfer. Proc. Natl. Acad. Sci. U S A. 93:12349-12354 (1996).

68. C. G. Dotti, R. G. Parton, and K. Simons. Polarized sorting of glypiated proteins in hippocampal neurons. Nature. 349:158161 (1991)

69. P. L. Cameron, T. C. Sudhof, R. Jahn, and P. De Camilli. Colocalization of synaptophysin with transferrin receptors: implications for synaptic vesicle biogenesis. J. Cell. Biol. 115:151-164 (1991).

70. J. S. Suk, J. Suh, K. Choy, S. K. Lai, J. Fu, and J. Hanes. Gene delivery to differentiated neurotypic cells with RGD and HIV Tat peptide functionalized polymeric nanoparticles. Biomaterials. 27:5143-5150 (2006)

71. R. K. Margolis, S. R. Salton, and R. U. Margolis. Effects of nerve growth factor-induced differentiation on the heparan sulfate of PC12 pheochromocytoma cells and comparison with developing brain. Arch. Biochem. Biophys. 257:107-114 (1987).

72. J. M. Bergen and S. H. Pun. Analysis of the intracellular barriers encountered by nonviral gene carriers in a model of spatially-controlled delivery to neurons. J. Gene Medicine (2007) in press.

73. J. S. Suk, J. Suh, S. K. Lai, and J. Hanes. Quantifying the intracellular transport of viral and nonviral gene vectors in primary neurons. Exp. Biol. Med. (Maywood) 232:461-469 (2007).

74. E. Wagner. Application of membrane-active peptides for nonviral gene delivery. Adv. Drug Deliv. Rev. 38:279-289 (1999).

75. I. S. Zuhorn, U. Bakowsky, E. Polushkin, W. H. Visser, M. C. Stuart, J. B. Engberts, and D. Hoekstra. Nonbilayer phase of lipoplex-membrane mixture determines endosomal escape of genetic cargo and transfection efficiency. Mol. Ther. 11:801-810 (2005).

76. J. Suh, D. Wirtz, and J. Hanes. Efficient active transport of gene nanocarriers to the cell nucleus. Proc. Natl. Acad. Sci. US A. 100:3878-3882 (2003).

77. S. Papadopoulos, K. D. Jurgens, and G. Gros. Protein diffusion in living skeletal muscle fibers: dependence on protein size, fiber type, and contraction. Biophys. J. 79:2084-2094 (2000).

78. S. M. King. The dynein microtubule motor. Biochim. Biophys. Acta. 1496:60-75 (2000).
79. R. B. Vallee, J. C. Williams, D. Varma, and L. E. Barnhart. Dynein: An ancient motor protein involved in multiple modes of transport. J. Neurobiol. 58:189-200 (2004).

80. M. Lakadamyali, M. J. Rust, H. P. Babcock, and X. Zhuang. Visualizing infection of individual influenza viruses. Proc. Natl. Acad. Sci. U S A. 100:9280-9285 (2003).

81. D. McDonald, M. A. Vodicka, G. Lucero, T. M. Svitkina, G. G. Borisy, M. Emerman, and T. J. Hope. Visualization of the intracellular behavior of HIV in living cells. J. Cell. Biol. 159:441-452 (2002).

82. P. L. Leopold, G. Kreitzer, N. Miyazawa, S. Rempel, K. K. Pfister, E. Rodriguez-Boulan, and R. G. Crystal. Dynein- and microtubule-mediated translocation of adenovirus serotype 5 occurs after endosomal lysis. Hum. Gene Ther. 11:151-165 (2000).

83. K. Dohner, A. Wolfstein, U. Prank, C. Echeverri, D. Dujardin, R. Vallee, and B. Sodeik. Function of dynein and dynactin in herpes simplex virus capsid transport. Mol. Biol. Cell. 13:27952809 (2002).

84. G. A. Smith, and L. W. Enquist. Break ins and break outs: viral interactions with the cytoskeleton of Mammalian cells. Annu. Rev. Cell Dev. Biol. 18:135-161 (2002).

85. H. Mabit, M. Y. Nakano, U. Prank, B. Saam, K. Dohner, B. Sodeik, and U. F. Greber. Intact microtubules support adenovirus and herpes simplex virus infections. J. Virol. 76:9962-9971 (2002).

86. E. Mastrobattista, M. A. van der Aa, W. E. Hennink, and D. J. Crommelin. Artificial viruses: a nanotechnological approach to gene delivery. Nat. Rev. Drug Discov. 5:115-121 (2006).

87. R. N. Cohen, M. J. Rashkin, X. Wen, and F. C. Szoka. Molecular motors as drug delivery vehicles. Drug Discovery Today: Technologies. 2:111-118 (2005).

88. J. M. Bergen, and S. H. Pun. Evaluation of an LC8-binding peptide for the attachment of artificial cargo to dynein. Mol. Pharm. 4:119-128 (2007).

89. M. A. van der Aa, E. Mastrobattista, R. S. Oosting, W. E. Hennink, G. A. Koning, and D. J. Crommelin. The nuclear pore complex: the gateway to successful nonviral gene delivery. Pharm. Res. 23:447-459 (2006).

90. Y. L. Chiu, A. Ali, C. Y. Chu, H. Cao, and T. M. Rana. Visualizing a correlation between siRNA localization, cellular uptake, and RNAi in living cells. Chem. Biol. 11:1165-1175 (2004).

91. R. Levi-Montalcini, and P. U. Angeletti. Nerve growth factor. Physiol. Rev. 48:534-569 (1968).

92. B. Georgievska, D. Kirik, and A. Bjorklund. Aberrant sprouting and downregulation of tyrosine hydroxylase in lesioned nigrostriatal dopamine neurons induced by long-lasting overexpression of glial cell line derived neurotrophic factor in the striatum by lentiviral gene transfer. Exp. Neurol. 177:461-474 (2002).

93. C. Rosenblad, B. Georgievska, and D. Kirik. Long-term striatal overexpression of GDNF selectively downregulates tyrosine hydroxylase in the intact nigrostriatal dopamine system. Eur. J. Neurosci. 17:260-270 (2003).

94. E. V. van Gaal, W. E. Hennink, D. J. Crommelin, and E. Mastrobattista. Plasmid engineering for controlled and sustained gene expression for nonviral gene therapy. Pharm. Res. 23:1053-1074 (2006).

95. J. A. Benitez, and J. Segovia. Gene therapy targeting in the central nervous system. Curr. Gene. Ther. 3:127-145 (2003).

96. M. C. de Lima, M. T. da Cruz, A. L. Cardoso, S. Simoes, and L. P. de Almeida. Liposomal and viral vectors for gene therapy of the central nervous system. Curr. Drug Targets CNS Neurol. Disord. 4:453-465 (2005).

97. S. A. Betchen, and M. Kaplitt. Future and current surgical therapies in Parkinson's disease. Curr. Opin. Neurol. 16:487-493 (2003).

98. S. B. Dunnett, and A. E. Rosser. Cell therapy in Huntington's disease. NeuroRx. 1:394-405 (2004).

99. D. J. Begley. Delivery of therapeutic agents to the central nervous system: the problems and the possibilities. Pharmacol. Ther. 104:29-45 (2004).

100. T. A. Read, F. Thorsen, and R. Bjerkvig. Localised delivery of therapeutic agents to CNS malignancies: old and new approaches. Curr. Pharm. Biotechnol. 3:257-273 (2002). 
101. M. J. During, M. G. Kaplitt, M. B. Stern, and D. Eidelberg. Subthalamic GAD gene transfer in Parkinson disease patients who are candidates for deep brain stimulation. Hum. Gene Ther. 12:1589-1591 (2001).

102. B. Schwartz, C. Benoist, B. Abdallah, R. Rangara, A. Hassan, D. Scherman, and B. A. Demeneix. Gene transfer by naked DNA into adult mouse brain. Gene Ther. 3:405-411 (1996).

103. H. Sato, S. Hattori, S. Kawamoto, I. Kudoh, A. Hayashi, I. Yamamoto, M. Yoshinari, M. Minami, and H. Kanno. In vivo gene gun-mediated DNA delivery into rodent brain tissue. Biochem. Biophys. Res. Commun. 270:163-170 (2000).

104. H. Peluffo, L. Acarin, A. Aris, P. Gonzalez, A. Villaverde, B. Castellano, and B. Gonzalez. Neuroprotection from NMDA excitotoxic lesion by $\mathrm{Cu} / \mathrm{Zn}$ superoxide dismutase gene delivery to the postnatal rat brain by a modular protein vector. $B M C$ Neurosci. 7:35 (2006).

105. Y. Hagihara, Y. Saitoh, Y. Kaneda, E. Kohmura, and T. Yoshimine. Widespread gene transfection into the central nervous system of primates. Gene Ther. 7:759-763 (2000).

106. J. Siepmann, F. Siepmann, and A. T. Florence. Local controlled drug delivery to the brain: mathematical modeling of the underlying mass transport mechanisms. Int. J. Pharm. 314:101-119 (2006)

107. S. Kalyanasundaram, V. D. Calhoun, and K. W. Leong. A finite element model for predicting the distribution of drugs delivered intracranially to the brain. Am. J. Physiol. 273:R1810-1821 (1997).

108. R. H. Bobo, D. W. Laske, A. Akbasak, P. F. Morrison, R. L. Dedrick, and E. H. Oldfield. Convection-enhanced delivery of macromolecules in the brain. Proc. Natl. Acad. Sci. US A. 91:2076-2080 (1994).

109. P. Hadaczek, Y. Yamashita, H. Mirek, L. Tamas, M. C. Bohn, C. Noble, J. W. Park, and K. Bankiewicz. The "perivascular pump" driven by arterial pulsation is a powerful mechanism for the distribution of therapeutic molecules within the brain. Mol. Ther. 14:69-78 (2006).

110. M. T. Krauze, R. Saito, C. Noble, J. Bringas, J. Forsayeth, T. R. McKnight, J. Park, and K. S. Bankiewicz. Effects of the perivascular space on convection-enhanced delivery of liposomes in primate putamen. Exp. Neurol. 196:104-111 (2005).

111. J. A. MacKay, D. F. Deen, and F. C. Szoka, Jr. Distribution in brain of liposomes after convection enhanced delivery; modulation by particle charge, particle diameter, and presence of steric coating. Brain Res. 1035:139-153 (2005).

112. M. Y. Chen, R. R. Lonser, P. F. Morrison, L. S. Governale, and E. H. Oldfield. Variables affecting convection-enhanced delivery to the striatum: a systematic examination of rate of infusion, cannula size, infusate concentration, and tissuecannula sealing time. J. Neurosurg. 90:315-320 (1999).

113. C. Mamot, J. B. Nguyen, M. Pourdehnad, P. Hadaczek, R. Saito, J. R. Bringas, D. C. Drummond, K. Hong, D. B. Kirpotin, T. McKnight, M. S. Berger, J. W. Park, and K. S. Bankiewicz. Extensive distribution of liposomes in rodent brains and brain tumors following convection-enhanced delivery. J. Neurooncol. 68:1-9 (2004).

114. M. Y. Chen, A. Hoffer, P. F. Morrison, J. F. Hamilton, J. Hughes, K. S. Schlageter, J. Lee, B. R. Kelly, and E. H. Oldfield. Surface properties, more than size, limiting convective distribution of virus-sized particles and viruses in the central nervous system. J. Neurosurg. 103:311-319 (2005).

115. K. B. Neeves, C. T. Lo, C. P. Foley, W. M. Saltzman, and W. L. Olbricht. Fabrication and characterization of microfluidic probes for convection enhanced drug delivery. J. Control Release. 111:252-262 (2006).

116. G. H. Huynh, T. Ozawa, D. F. Deen, T. Tihan, and F. C. Szoka, Jr. Retro-convection enhanced delivery to increase blood to brain transfer of macromolecules. Brain Res. (2006).

117. D. D. Heistad and F. M. Faraci. Gene therapy for cerebral vascular disease. Stroke. 27:1688-1693 (1996).

118. J. G. Hecker, L. L. Hall, and V. R. Irion. Nonviral gene delivery to the lateral ventricles in rat brain: initial evidence for widespread distribution and expression in the central nervous system. Mol. Ther. 3:375-384 (2001).
119. D. M. Anderson, L. L. Hall, A. R. Ayyalapu, V. R. Irion, M. H. Nantz, and J. G. Hecker. Stability of mRNA/cationic lipid lipoplexes in human and rat cerebrospinal fluid: methods and evidence for nonviral mRNA gene delivery to the central nervous system. Hum. Gene Ther. 14:191-202 (2003).

120. L. F. Kromer. Nerve growth factor treatment after brain injury prevents neuronal death. Science. 235:214-216 (1987).

121. L. L. Zou, L. Huang, R. L. Hayes, C. Black, Y. H. Qiu, J. R. Perez-Polo, W. Le, G. L. Clifton, and K. Yang. Liposomemediated NGF gene transfection following neuronal injury: potential therapeutic applications. Gene Ther. 6:994-1005 (1999).

122. D. K. Cope, and W. R. Lariviere. Gene therapy and chronic pain. ScientificWorld J. 6:1066-1074 (2006).

123. G. P. Tang, H. Y. Guo, F. Alexis, X. Wang, S. Zeng, T. M. Lim, J. Ding, Y. Y. Yang, and S. Wang. Low molecular weight polyethylenimines linked by beta-cyclodextrin for gene transfer into the nervous system. J. Gene Med. 8:736-744 (2006).

124. M. Box, D. A. Parks, A. Knight, C. Hale, P. S. Fishman, and N. F. Fairweather. A multi-domain protein system based on the HC fragment of tetanus toxin for targeting DNA to neuronal cells. J. Drug Target. 11:333-343 (2003).

125. H. Schneider, M. Groves, C. Muhle, P. N. Reynolds, A. Knight, M. Themis, J. Carvajal, F. Scaravilli, D. T. Curiel, N. F. Fairweather, and C. Coutelle. Retargeting of adenoviral vectors to neurons using the Hc fragment of tetanus toxin. Gene Ther. 7:1584-1592 (2000).

126. H. B. Rind, R. Butowt, and C. S. von Bartheld. Synaptic targeting of retrogradely transported trophic factors in motoneurons: comparison of glial cell line-derived neurotrophic factor, brain-derived neurotrophic factor, and cardiotrophin-1 with tetanus toxin. J. Neurosci. 25:539-549 (2005).

127. R. S. Devon, P. C. Orban, K. Gerrow, M. A. Barbieri, C Schwab, L. P. Cao, J. R. Helm, N. Bissada, R. Cruz-Aguado, T. L. Davidson, J. Witmer, M. Metzler, C. K. Lam, W. Tetzlaff, E. M. Simpson, J. M. McCaffery, A. E. El-Husseini, B. R. Leavitt, and M. R. Hayden. Als2-deficient mice exhibit disturbances in endosome trafficking associated with motor behavioral abnormalities. Proc. Natl. Acad. Sci. U S A. 103:9595-9600 (2006).

128. C. M. Wiethoff, and C. R. Middaugh. Barriers to nonviral gene delivery. J. Pharm. Sci. 92:203-217 (2003).

129. I. K. Park, T. H. Kim, S. I. Kim, T. Akaike, and C. S. Cho. Chemical modification of chitosan for gene delivery. J. Dispers. Sci. Technol. 24:489-498 (2003).

130. R. J. Boado. RNA interference and nonviral targeted gene therapy of experimental brain cancer. NeuroRx. 2:139-150 (2005).

131. W. M. Pardridge. Tyrosine hydroxylase replacement in experimental Parkinson's disease with transvascular gene therapy. NeuroRx. 2:129-138 (2005).

132. W. M. Pardridge. Blood-brain barrier delivery. Drug Discov. Today. 12:54-61 (2007).

133. S. E. Doran, X. D. Ren, A. L. Betz, M. A. Pagel, E. A. Neuwelt, B. J. Roessler, and B. L. Davidson. Gene expression from recombinant viral vectors in the central nervous system after blood-brain barrier disruption. Neurosurgery. 36:965-970 (1995).

134. N. G. Rainov, K. Ikeda, N. Qureshi, S. Grover, F. H. Barnett, U. Herrlinger, A. Quinones, E. A. Chiocca, and X. O. Breakefield. Intra-arterial virus and nonvirus vector-mediated gene transfer to experimental rat brain tumors. Front. Radiat. Ther. Oncol. 33:227-240 (1999).

135. N. G. Rainov, K. Ikeda, N. H. Qureshi, S. Grover, U. Herrlinger, P. Pechan, E. A. Chiocca, X. O. Breakefield, and F. H. Barnett. Intraarterial delivery of adenovirus vectors and liposome-DNA complexes to experimental brain neoplasms. Hum. Gene Ther. 10:311-318 (1999).

136. A. Nadal, E. Fuentes, J. Pastor, and P. A. McNaughton. Plasma albumin is a potent trigger of calcium signals and DNA synthesis in astrocytes. Proc. Natl. Acad. Sci. U S A. 92:14261430 (1995).

137. A. S. Lossinsky, A. W. Vorbrodt, and H. M. Wisniewski. Scanning and transmission electron microscopic studies of 
microvascular pathology in the osmotically impaired bloodbrain barrier. J. Neurocytol. 24:795-806 (1995).

138. T. S. Salahuddin, B. B. Johansson, H. Kalimo, and Y. Olsson. Structural changes in the rat brain after carotid infusions of hyperosmolar solutions. An electron microscopic study. Acta Neuropathol. (Berl) 77:5-13 (1988).

139. J. Huwyler, D. Wu, and W. M. Pardridge. Brain drug delivery of small molecules using immunoliposomes. Proc. Natl. Acad. Sci. U S A. 93:14164-14169 (1996).
140. F. Schlachetzki, Y. Zhang, R. J. Boado, and W. M. Pardridge. Gene therapy of the brain: the trans-vascular approach. Neurology. 62:1275-1281 (2004).

141. N. Shi, Y. Zhang, C. Zhu, R. J. Boado, and W. M. Pardridge. Brain-specific expression of an exogenous gene after i.v. administration. Proc. Natl. Acad. Sci. U S A. 98:12754-12759 (2001).

142. Y. Zhang, F. Schlachetzki, and W. M. Pardridge. Global nonviral gene transfer to the primate brain following intravenous administration. Mol. Ther. 7:11-18 (2003). 